AUTHOR CORRECTION

\title{
Author Correction: 6-month follow-up of VIALE-C demonstrates improved and durable efficacy in patients with untreated AML ineligible for intensive chemotherapy
}

Andrew H. Wei (D, Panayiotis Panayiotidis, Pau Montesinos (D), Kamel Laribi, Vladimir Ivanov, Inho Kim, Jan Novak, Don A. Stevens, Walter Fiedler, Maria Pagoni, Julie Bergeron, Stephen B. Ting (D), Jing-Zhou Hou, Achilles Anagnostopoulos (D), Andrew McDonald, Vidhya Murthy, Takahiro Yamauchi, Jianxiang Wang, Brenda Chyla, Yan Sun, Qi Jiang, Wellington Mendes (D), John Hayslip and Courtney D. DiNardo

(c) The Author(s) 2021

Blood Cancer Journal (2021)11:171; https://doi.org/10.1038/s41408-021-00565-6

Correction to: Blood Cancer Journal https://doi.org/10.1038/ s41408-021-00555-8, published online 01 October 2021

The title this article was published with was not correct. It should read "6-month follow-up of VIALE-C demonstrates improved and durable efficacy in patients with untreated $A M L$ ineligible for intensive chemotherapy".

\begin{abstract}
(c) (i) Open Access This article is licensed under a Creative Commons C. Attribution 4.0 International License, which permits use, sharing, adaptation, distribution and reproduction in any medium or format, as long as you give appropriate credit to the original author(s) and the source, provide a link to the Creative Commons license, and indicate if changes were made. The images or other third party material in this article are included in the article's Creative Commons license, unless indicated otherwise in a credit line to the material. If material is not included in the article's Creative Commons license and your intended use is not permitted by statutory regulation or exceeds the permitted use, you will need to obtain permission directly from the copyright holder. To view a copy of this license, visit http://creativecommons. org/licenses/by/4.0/.
\end{abstract}

(c) The Author(s) 2021 